\title{
MENEROPONG FREKUENSI PRAKTEK \\ PERKAWINAN DIBAWAH UMUR DI KOTA BIMA
}

\author{
Yayuk Kusumawati, M. Pd. \\ Institut Agama Islam (IAI) Muhammadiyah Bima \\ Jl. Anggrek No. 16 Ranggo Na'e Kota Bima \\ yayukalkhansa@gmail.com
}

\section{Abstrak}

Menikah adalah fitrah bagi manusia dan merupakan perintah dari Allah, Negara pun mengatur tentang pernikahan yang tertuang dalam undang-undang perkawinan nomor 1 tahun 1974 pasal 1, selain itu juga perundang-undangan mengatur tentang batasan umur perkawinan sebagaimana tertuang dalam pasal 7 bahwa laki-laki menikah ketika mencapai umur 19 tahun dan perempuan mencapai 16 tahun, dengan adanya legalitas dispensasi nikah ini justru semakin marak dan mencari celah agar tercapainya pernikahan yang diinginkan padahal secara mental belum tentu siap seperti orang dewasa, maka dari itu yang menjadi kajian dalam penelitian ini adalah proses terjadinya perkawinan dibawah umur dan solusi pemerintah untuk meminimalisir terjadinya perkawinan dibawah umur. Hasil penelitian menunjukan bahwa tingkat perkawinan dibawah umur meningkat setiap tahunnya yaitu 2017 sebanyak 59 \%, 2018 sebanyak 93\% dan 2019 sebanyak 90\%, faktor dikabulkannya perkwinan dibawah umur yaitu akibat hamil terlebih dahulu sebelum melakukan perkawinan serta tidak semua pengajuan dispensasi nikah dikabulkan oleh hakim dengan pertimbangan masih umur yang begitu kecil misal dibawah 
15 tahun karena secara mental dan psikologi belum mampu untuk membangun rumah tangga dengan matang.

\section{Kata kunci : Perkawinan, Dibawah Umur, Kota Bima}

\section{Pendahuluan}

Salah satu anugerah Allah yang menjadi titipan sang pencipta kepada makhluknya adalah dengan adaanya anak yang kelak bisa mencetak generasi yang mengikuti al-Quran dan assunah, karena anak adalah aset yang harus dijaga dan dibimbing yang menjadi harapan kelak sebagai generasi yang bisa membanggakan Bangsa dan Negara lebih khusus untuk Agama dan keluarga, melalui mengecap pendidikan salah satu jalan untuk terwujudnya hal tersebut, sebagaimana yang diamanatkan dalam pembukaan UUD 1945 Alinea-4 di sebagian kutipan ayatnya yaitu"...mencerdaskan kehidupan bangsa..," ${ }^{\prime \prime}$ karena ketika rakyat cerdas maka sensitivitas dengan nasib bangsa akan peka dengan ilmu yang didapat, harapan bagi bangsa bahwa anak adalah aset Negara yang harus dididik, dibimbing dengan melalui pendidikan formal maupun informal di lingkungan keluarga tersebut, maka nilai, norma, moral dan beretika bisa dijalankan dengan baik serta mampu melebur dengan baik dalam kehidupan sosial, dan juga dalam menjaga keharmonisan untuk itu perlu pemerintah ikut andil menjaga masa depan anak agar tidak akan terjadi hal yang tidak diinginkan salah satunya yaitu terjadinya perkawinan di bawah umur.

Perkawinan merupakan salah satu solusi real untuk mencetak generasi yang diharapkan tentunya melalui ramburambu religi yang ditanamkan, menikah merupakan jalan yang ditempuh dengan memenuhi zona keamanan baik secara lahiriah maupun batiniah dalam sejarah kenabian ada salah satu Istri Nabi

$1 \quad$ Kitab Undang-Undang Dasar 1945. 2017 Jakarta: Majelis Permusyawaratan Rakyat

Sangaji Jurnal Pemikiran Syariah dan Hukum 
Muhammad yaitu Aisyah yang dinikahinya pada usia kisaran 6 tahun digauli pada saat balig ${ }^{2}$ akan tetapi ini bukan berarti kita jadikan sebuah hujjah bahwa dibolehkan anak di bawah umur untuk menikah. Secara eksplisit beda kondisi, beda mental dan wawasan keilmuan, permasalahannya generasi sekarang apalagi anak di bawah umur hanya berdasarkan perasaan suka saja, dengan cara bergaul yang tidak sesuai syari'ah terjadi hal yang tidak diinginkan dan kemudian jalan satu-satunya perspektif mereka adalah melakukan perkawinan. Sehingga terjadilah celah hukum untuk mencari jalan agar mensahkan perbuatan tersebut, walaupun dalam hal ini pemerintah telah membuat batasan umur perkawinan sebagaimana tercantum dalam UU Nomor 1 Tahun 1974 pasal 7 ayat 1 yang berbunyi "Perkawinan hanya diizinkan jika pihak pria sudah mencapai umur 19 (sembilan belas) tahun dan pihak wanita sudah mencapai umur 16 (enam belas) tahun" ${ }^{3 \prime}$, harapannya adalah ketika menikah tidak cukup umur maka akan berakibat pada rumah tangga yang dibangun menjadi retak hanya karena persoalan ekonomi, mental belum siap dan lain sebagainnya, melanjutkan dari Pasal di atas justru di pasal 7 ayat 2 menimbulkan inkonsistensi produk hukum sebagaimana berbunyi "Dalam hal terjadi penyimpangan terhadap ketentuan umur sebagaimana dimaksud pada ayat (1), orang tua pihak pria dan/atau orang tua pihak wanita dapat meminta dispensasi kepada Pengadilan dengan alasan sangat mendesak disertai bukti-bukti pendukung yang cukup." Artinya pasal 7 ayat 1 diatas menjadi tumbang dan lemah ketika dihadapkan dengan pasal 7 ayat 2 dan akan dijadikan sebuah celah hukum yang bisa melegalkan dan mensahkan pekawinan di bawah umur.

${ }^{2}$ M. Ali harakan, 2012. Sirah Nabawiyah. Jakarta : Pustaka Al-Kautsar hal 578

3 Undang-undang Republik Indonesia Nomor 1 tahun 1974 tentang Perkawinan dan Kompilasi Hukum Islam. 2014. Jakarta: Grahamedia Press 
Undang-undang perkawinan yang di anggap sebagai perlindungan bagi anak menimbulkan inkonsisten, maka hal yang terjadi tidak mampu di cegah dan akan terus berulang-ulang hal ini diperkuat dengan data yang diperoleh pada observasi awal peneliti bahwa selama 3 tahun terakhir dari tahun 2017-2019 jumlah yang mengajukan dispensasi nikah yaitu 164 dengan rincian tahun 2017 sebanyak 68 orang, tahun 2018 sebanyak 76 orang dan tahun 2019 sebanyak 20 orang dari Januari sampai 06 Maret, artinya sekian tahun ada peningkatan begitupun dengan tahun 2019 dalam jangka waktu 2 bulan ${ }^{4}$. Hal ini bisa terjadi karena sebuah pola perilaku yang menyimpang dalam kehidupan sosial, harapan anak yang seharusnya kelak menjadi aset bangsa yang berharga justru menjadi boomerang untuk Negara sendiri akibat pergaulan yang bebas maka hal yang tidak diharapkan terjadi yaitu perkawinan yang semestinya usia anak memiliki batas faktanya usia tersebut secara pikiran, mental belum begitu matang ketika dipaksa untuk berperan sebagai orang dewasa dengan masalah yang lebih besar yaitu perkawinan di bawah umur. Hukum perkawinan dari segi hukum positif hal ini boleh dilakukan jika ada yang namanya dispensasi nikah yang diberikan oleh pejabat yang berwenang sebagaimana yang tertuang dalam pasal 7 ayat 2 UU No.1 Tahun 1974 terkait dispensasi nikah.

Perlu ada regulasi yang kuat dan produk hukum yang konsisten agar tidak memiliki dalih untuk mencari celah pembenaran perkawinan di bawah umur yang akhirnya bisa menjadi budaya dan menekan pertumbuhan anak, stakeholder yang dianggap mampu untuk berperan menjaga anak bangsa karena pada hakekatnya tujuan perkawinan adalah membentuk keluarga yang bahagia dan kekal berdasarkan Ketuhanan Yang Maha Esa5,

${ }^{4}$ Data diperoleh dari Pengadilan Agama Bima dan diperkuat dari sumber (http://sipp.pa-bima.go.id).

${ }^{5}$ Undang-undang perkawinan di Indonesia No.1 Tahun 1974, Surabaya : Arkola pasal 1

Sangaji Jurnal Pemikiran Syariah dan Hukum 
sebagaimana yang diamanatkan dalam undang-undang perkawinan.

\section{Perkawinan di Bawah Umur dalam Hukum Positif}

Perkawinan di bawah umur adalah perkawinan yang dilakukan di bawah usia yang disediakan serta disiapkan untuk dewasa yang diperbarui dan perbaikan rumah tangga ${ }^{6}$. Yang dimaksud dalam hal ini adalah anak yang tidak sesuai batas perkawinan yaitu laki-laki harus berusia 19 tahun dan perempuan berusia 16 tahun, jika perkawinan terjadi di bawah usia batas yang telah menjadi peraturan maka perkawinan tersebut disebut sebagai perkawinan di bawah umur.

Dengan demikian usia perkawinan memiliki batasan, yaitu menurut perundangan secara yuridis formal bahwa dalam pasal 7 ayat (1) Undang-undang No.1 Tahun 1974 perkawinan hanya diizinkan jika pihak pria sudah mencapai umur 19 tahun dan pihak wanita sudah mencapai umur 16 tahun. Itu artinya, pria dan wanita yang usianya di bawah ketentuan tersebut belum boleh melaksanakan perkawinan. Jika kedua calon tidak memiliki orang tua lagi atau orang tua yang bersangkutan tidak mampu menyatakan kehendaknya, misalnya karena memiliki kemunduran ingatan, sakit jiwa, atau lainnya, maka izin yang dimaksud yang diperoleh dari wali, atau orang yang memelihara, atau keluarga yang mempunyai hubungan darah dengan kedua calon mempelai dalam garis ke atas selama mereka masih hidup dan mampu menyatakan kehendaknya.

Dalam hal seorang dari kedua orang tua meninggal dunia atau dalam keadaan tidak mampu menyatakan kehendaknya, maka izin yang dimaksud ayat (2) pasal 6 ini cukup diperoleh dari orang tua yang masih hidup atau dari orang tua yang mampu menyatakan kehendaknya. Maka izin diperoleh dari wali orang

6 Nukman, 2009. Yang Dimaksud Dengan Pernikahan Dini. Yogyakarta : paradigma hal 32 
yang memelihara atau keluarga yang mempunyai hubungan darah dan garis keturunan lurus ke atas selama mereka masih hidup dan dalam keadaan mampu menyatakan kehendaknya (pasal 6 [3-4] Undang-undang Perkawinan Nomor 1 Tahun 1974).

Perundangan memberikan batas dalam perkawinan agar bisa menjaga kesehatan suami-istri dan keturunan, dengan demikian, peraturan usia ini sesungguhnya sesuai dengan prinsip perkawinan yang menyatakan bahwa calon suami dan istri harus telah matang jiwa dan raganya. Tujuannya agar perkawinan itu menciptakan keluarga yang langgeng dan bahagia, serta memberikan keturunan yan sehat tanpa bberujung pada perceraian dan prematur. Selain itu juga jika perkawinan terjadi tidak sesuai dengan perundangan yaitu umur perkawinan tidak memenuhi syarat maka akan diberikan dispensasi sesuai dengan pasal 13 keputusan Menteri Agama Nomor 298 Tahun 2003 tentang pencatatan nikah bahwa "apabila seorang calon suami belum mencapai umur 19 tahun dan calon istri belum mencapai 16 tahun, harus mendapat dispensasi dari pengadilan".

Dalam artian misalnya karena pergaulan bebas yang permisif (kumpul kebo, hamil di luar nikah dan sebagainya), maka Undangundang perkawinan No.1 tahun 1974 memberikan kemungkinan untuk menyimpang dari batas usia tersebut. Dalam keadaan darurat seperti itu, diperbolehkan untuk meminta dispensasi kepada pengadilan atau pejabat lain yang ditunjuk oleh kedua orang tua dari pihak pria maupun wanita.

\section{Perkawinan Di Bawah Umur dalam Aspek Sosial}

Perkawinan merupakan bentuk tindakan sosial budaya, sedikit menyangkut kedudukan sosial yang bersangkutan ${ }^{7}$. Pada umumnya perkawinan berlangsung antara orang-orang yang mempunyai kedudukan sosial yang sederajat. Terkadang

7 Anshary, M. 2010. Hukum Perkawinan di Indonesia (Masalah-masalah Krusial). Yogyakarta: Pustaka Pelajar. hlm 277-278

Sangaji Jurnal Pemikiran Syariah dan Hukum 
perkawinan tersebut menaikkan derajat seseorang atau bahkan menurunkan derajat mereka. Keadaan semacam itu terutama tampak pada masyarakat yang sistem stratifikasi sosialnya bersifat tertutup. Penjelasan tersebut tidak terlepas dari orientasi pemikiran tentang fungsi perkawinan bagi masyarakat Indonesia yang menganggap bahwa perkawinan sebagai suatu sistem sosial budaya yang dapat mengangkat status keluarga di tengah-tengah masyarakat. Prinsip seperti ini masih cukup besar pengaruhnya, sehingga orang-orang yang stratifikasi ekonominya dan pendidikannya rendah, semakin cenderung mendorong putra putrinya melangsungkan perkawinan di bawah umur.

Pemikiran masyarakat telah mengakui kehadiran perkawinan di bawah umur tersebut tidak membuat tercengang dalam lingkup masyarakat walaupun di era teknologi sekarang ini artinya, sebelum terjadinya perubahan teknologi terlebih dahulu telah terjadi perubahan gagasan baru dalam pola pikir ${ }^{8}$. Gagasan baru tidak terpengaruh dengan minimnya perkawinan di bawah umur justru hal ini tidak dianggap tabuh sehingga pergaulan bebas terjadi karena usaha memfilter diri tidak ada, keluarga, lingkungan sosial yang terutama. Di era sekarang ini justru anak dipaksakan untuk dewasa, tingkah laku, pola pikir dan lain sebagainya akhirnya tindakan apapun berada di luar jalur kesanggupannya. Hal ini tidak bisa dipungkiri bahwa perkawinan di bawah umur banyak yang melatarbelakangi oleh beberapa faktor, seperti faktor ekonomi, pendidikan, sosial budaya, dan lingkungan. Faktor-faktor tersebut merupakan sebab yang dapat mendorong terjadinya perkawinan di bawah umur, bahkan karena faktor lemahnya ekonomi dan sosial budaya merupakan yang sangat dominan, suatu kenyataan dalam masyarakat bahwa anak yang putus sekolah disebabkan tidak adanya biaya, sehingga jika

${ }^{8}$ Maspupah, Ade. 2014. People's Perseption About Early Marriage (A Case Study In Desa Sungai Kuning Kecamatan Singingi Kabupaten Kuantan Singingi). Jom FISIP Volume 1 No( 2), 1 - 15. 
seorang anak putus sekolah maka peluang dan dorongan cepat kawin semakin kuat9.

Padahal perkawinan yang ideal untuk perempuan adalah 2125 tahun sementara laki-laki 25-28 tahun karena di usia itu organ reproduksi perempuan secara psikologis sudah berkembang dengan baik dan kuat serta siap untuk melahirkan keturunan secara fisik pun mulai matang ${ }^{10}$, begitupun dengan kondisi lakilaki baik secara psikis emosional, ekonomi dan sosial. Melakukan perkawinan tanpa kesiapan dan pertimbangan yang matang dari satu sisi dapat mengindikasikan sikap tidak apresiatif terhadap makna perkawinan, sebagian masyarakat yang melangsungkan perkawinan di bawah umur ini dipengaruhi karena adanya berbagai macam faktor yang mendorong mereka untuk melangsungkan perkawinan di bawah umur ${ }^{11}$. Melalui keadaan seperti itu secara aspek sosial perkawinan di bawah umur setidaknya menjadi suatu hal yang tabuh di masyarakat agar orang tua maupun anak tidak menjadikan alasan pembenaran untuk melakukannya, dengan begitu untuk melakukan pergaulan yang negatif maupun perkawinan yang dilakukan antar kerelaan masing-masing individu ataupun keluarga bisa difilter kejadiannya. Hal ini semacam Punishment sosial yang diberikan agar sadar dengan tindakan tersebut, akan tetapi keseimbangan dasolen dan dasein inilah yang menjadi kenyataan bahwa keadaan sosial perkawinan di bawah umur menjadi hal biasa terjadi.

9 Hanif, Yusuf. 2011. Kontroversi Perkawinan Anak dibawah Umur (Child Marriage). Bandung: CV. Mandar Maju hlm 71

${ }^{10}$ Kumalasari, Intan dan Andhyantoro, Iwan. 2012. Kesehatan Reproduksi untuk Mahasiswa Kebidanan dan Keperawatan. Jakarta: Salemba Medika. Hlm 82

11 Mohammad, M. Dlori. (2005) Jeratan nikah dini, wabah pergaulan. Yogjakarta: Binar Press. Hlm 55

Sangaji Jurnal Pemikiran Syariah dan Hukum 


\section{Implikasi Perkawinan Di Bawah Umur}

Perkawinan di bawah umur yang dilakukan tidak bisa dipungkiri setiap keputusan yang di ambil akan memiliki konsekuensi hukum, secara suka ataupun tidak suka akan dialami oleh mereka yang melakukan hal tersebut antara lain :

\section{Putus Sekolah}

Hampir tidak bisa dipastikan pengantik anak adalah generasi putus sekolah dan bahkan yang tidak mengenyam pendidikan sama sekali, kesempatan mereka untuk mengenyam pendidikan yang lebih tinggi menjadi mimpi bahkan tidak sedikit pula yang tidak menyelesaikan bangku pendidikan dasar ${ }^{12}$.

\section{Kekerasan dalam rumah tangga}

Yang menjadi korban KDRT biasanya gadis muda yang dikawinkan di usia dini lazimnya bersuamikan pria yang berusia jauh lebih tua dari dirinya, akibat margin usia yang jauh inilah hampir muncul problem komunikasi keluarga, ekonomi maupun seksual diantara keduannya sehingga muncullah kekerasan dalam rumah tangga tersebut yang bisa menyakitkan pasangan dan yang menjadi korbannya adalah perempuan sebagai kaum rentan ${ }^{13}$.

\section{Perceraian}

Akibat tidak harmonisnya rumah tangga, maupun komunikasi yang tidak sejalan dengan kondisi rumah tangga perkawinan di bawah umur bisa berdampak pada terjadinya perceraian, hal ini tidak bisa dielakkan perempuan yang menjadi korban sulit dan bahkan tidak bisa melanjutkan sekolah bahkan malu untuk melanjutkan sekolah, status janda di usia muda pun menjadi identitas tersendiri. Perkawinan di

12 Gultom, Maidin. 2013. Perlindungan Hukum terhadap Anak dan Perempuan. Bandung: PT. Refika Aditama hlm 100

13 Khaeron Sirin. 2009. Fikih Perkawinan dibawah Umur. Jakarta: Ghalia Indonesia hlm 33 
bawah umur tidak jarang memunculkan banyak masalah yang sangat pelik di dalam rumah tangga dan kerap berakhir dengan perceraian $^{14}$.

Masih banyak dampak dari perkawinan di bawah umum jika ingin dieksplisitkan dengan rincian yang jelas akan tetapi yang paling krusial dan sering dialami yang berdampak sangat besar adalah ketiga poin di atas dan inferior perempuan atas subordinitas laki-lakilah jika implikasi dari perkawinan di bawah umur terjadi maka perempuan yang harus merasakan beban secara psikologis, moral, dan lain sebagainya, jadilah trending sosial ada penyebutan terkait "perempuan kepala keluarga", pulau "seribu janda", hal-hal semacam ini justru menjadi isu menarik dari konflik keluarga maupun sosial dan menyampingkan bagaimana menemukan solusi agar hukum tidak berlubang sehingga tidak ada celah untuk menemukan pembenaran sehingga perkawinan di bawah umur bisa difilter sedini mungkin untuk tidak terjadi.

\section{Frekuensi terwujudnya praktik perkawinan di bawah umur di Kota Bima.}

Untuk mencapai tujuan pernikahan berbagaimacam cara dilakukan agar mengakui dan dilaksanakan ucapan sacral yaitu perkawinan, salah satunya yaitu dengan adanya dispensasi nikah, peneliti menyebut dengan celah hukum dalam perkawinan karena dengan adanya peraturan Negara membolehkan perkawinan dibawah umur dengan adanya dispensasi nikah,

Di wilayah kota Bima dispensasi nikah menjadi marak dilakukan seperti trending pergaulan, hal ini terbukti dari data yang peneliti peroleh mulai tahun 2017-2019 dibawah ini :

${ }^{14}$ Wiliam. J. Goode. 1985. Sosiologi Hukum. Alih bahasa Hanoun Hasyim. Jakarta : Diaksara.

Hlm 110

Sangaji Jurnal Pemikiran Syariah dan Hukum 
Tabel 4.1 Tingkat Dispensasi Nikah di Kota Bima

\begin{tabular}{|c|c|c|l|}
\hline No & Tahun & Jumlah & Keterangan \\
\hline 1 & 2017 & 71 Orang & $\begin{array}{l}\text { Semua Jenis } \\
\text { Perkara }\end{array}$ \\
\hline 2 & 2018 & 77 Orang & $\begin{array}{l}\text { Semua Jenis } \\
\text { Perkara }\end{array}$ \\
\hline 3 & 2019 & 29 Orang & $\begin{array}{l}\text { Data diperoleh } \\
\text { hanya Bulan 1-7 } \\
\text { 2019 (semua } \\
\text { jenis perkara) }\end{array}$ \\
\hline
\end{tabular}

Sumber : Pengadilan Agama Bima

Berdasarkan data diatas yang menunjukan bahwa angka paling tinggi terjadi pada tahun 2018, kemudian tahun 2017 dan di ikuti data ditahun 2019 itupun data yang diperoleh perkara yang masuk dari bulan januari sampai juli, artinya akan ada peningkatan lagi data yang masuk di bulan setelahnya. Melihat frekuensi yang hampir mendekati hal ini menunjukan bahwa dengan adanya batasan usia perkawinan tidak akan menjamin seseorang untuk tidak melakukan perkawinan di bawah umur, karena di satu sisi pada pasal 7 ayat 2 justru memberikan peluang untuk melanggar pasal 7 ayat 1 .

Hal ini terbukti juga dari hasil wawancara terkait proses dilakukannya dispensasi nikah dengan hakim Imam Shofwan, M.Sy dan Drs. H. Mukminin, serta panitera Drs. H. Musaddad, SH yang memiliki jawaban hampir sama, maka kami merangkumnya yaitu:

1. Pengajuan dispensasi yang mengajukan adalah walinya yang meminta ijin, bisa calonnya juga atau orang yang menurut hukum catatan perkawinan, adapun proses persidangan dilakukan secara tertutup kami tidak bisa menggali info lebih 
dalam karena mengetahui proses persidangan sama saja dengan membuka aib pelaku perkawinan dibawah umur.

2. Tidak semua dispensasi nikah itu diberikan, kalau diterima dispensasi nikah itu karena sudah terjadi hubungan layaknya suami istri dengan dibuktikan adanya pengakuan dari kedua belah pihak serta pembuktian hasil pemeriksaan dari RS, apabila ditolak itu karena usia yang terlalu muda dibawah 15 Tahun serta tidak ada persetujuan disalah satu keluarga.

3. Secara umum dijelaskan dalam hukum mestinya dalam sebuah pernikahan itu harus mampu secara fisik dan psikis, fisik maksudnya badannya kuat, psikis begitu juga dan berkaitan dengan umur itu kalau kondisi ideal, tapi karena kondisi darurat jadi diterima.

\section{Kebijakan dan program solutif untuk mencegah terjadinya perkawinan di bawah umur di Kota Bima.}

Hasil wawancara dengan hakim Imam Shofwan, M.Sy Agustus 2019 terkait kebijakan dan program yang solutif biasanya diambil alih oleh pihak KUA untuk melakukan sosialisasi terkait perkawinan dibawah umur dengan menggandeng dinas kesehatan, BKKBN dan lain sebaginnya sebagai bentuk kepedulian pemerintah dalam menekan pertumbuhan perkawinan dibawah umur. Ia pun menambahkan bahwa kita tidak bisa sepenuhnya berharap kepada pemerintah akan tetapi control keluarga juga perlu untuk dilakukan agar keseimbangan terjadi untuk menjaga generasi bangsa.

Berdasarkan penelitian pada bulan Juli s/d Agustus 2019, peneliti telah memperoleh data di Pengadilan Agama dengan melakukan wawancara pada Hakim 2 orang dan panitera 1 orang, terkait proses dipenuhinya perkawinan dibawah umur 
sebagaimana hasil wawancara sebelumnya, maka dapat digambarkan sebagaimana terlihat pada rasio data dibawah ini :

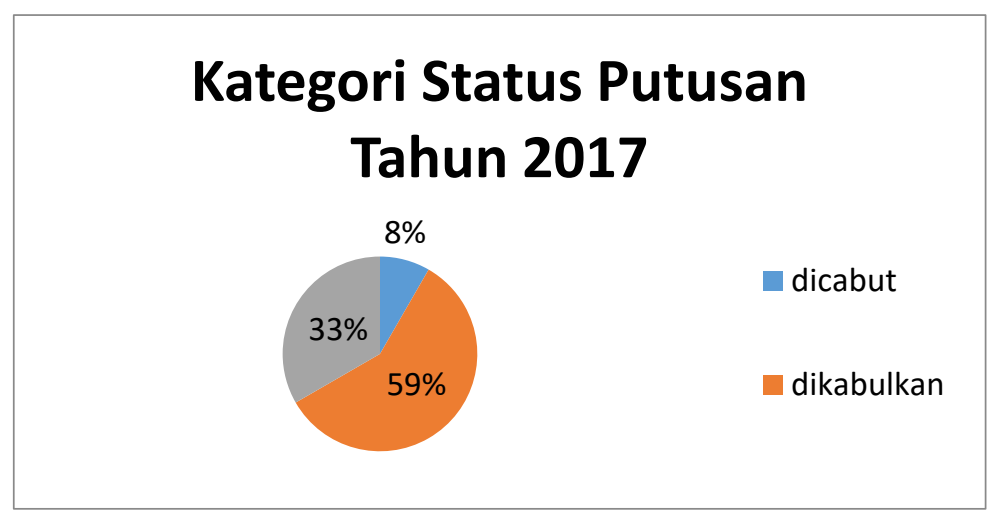

Terlihat dari gambar diatas bahwa $59 \%$ dikabulkan terkait dispensasi nikah lebih besar dari dicabut $8 \%$ dan tidak dapat diterima $33 \%$, hal ini menunjukan bahwa ditahun 2017 tingkat perkawinan di bawah umur tinggi terjadi dengan berbagai macam faktor seperti kebanyakan karena telah melakukan hubungan layaknya suami istri dan hamil terlebih dahulu tanpa melalui proses hubungan yang sah menurut aturan positif maupun agama Islam.

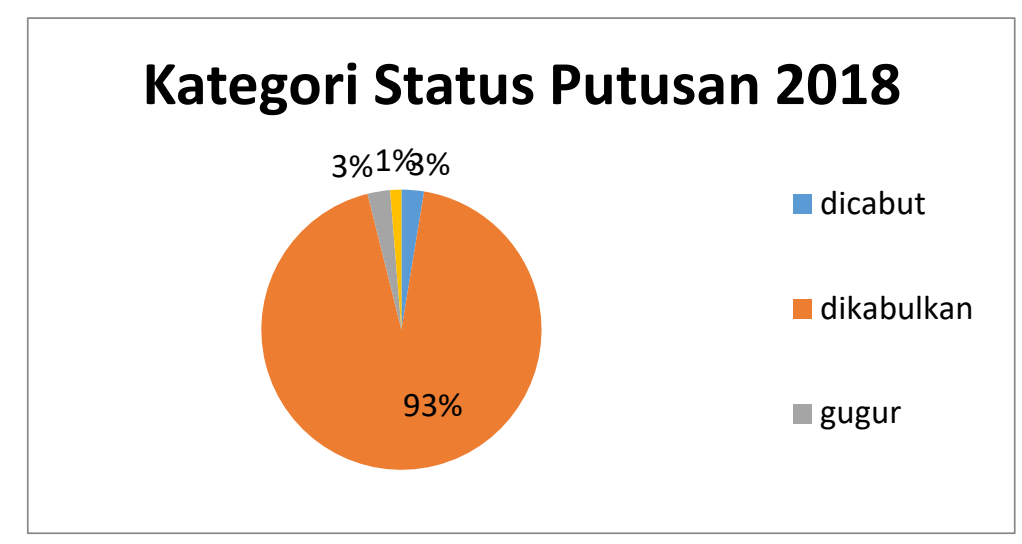

Ditahun 2018 peningkatan terjadi yaitu $93 \%$ dikabulkan dengan faktor yang sama dengan tahun sebelumnya, hal ini 
memperkuat bahwa hukum menjadi lemah ditengah kehidupan sosial masyarakat. Keberadaan HAM, aturan positif terkait perkawinan dan lain sebagainya.

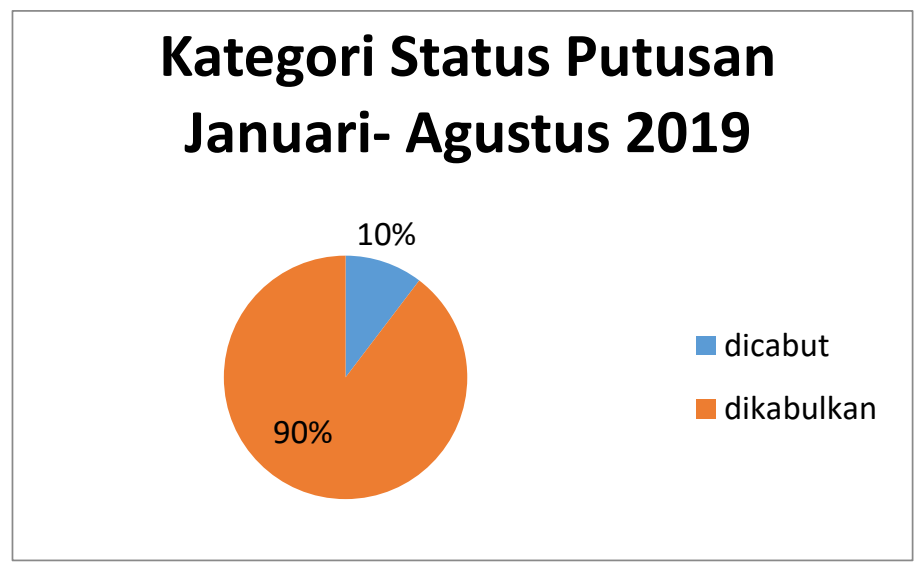

Dapat dilihat dari gambar diatas bahwa siklus perkawinan dibawah umur mengalami peningkatan dari tahun ke tahun, data ini menjadi indikator bahwa pemerintah belum mampu memberikan solusi yang preventif untuk menekan laju perkembangan perkawinan dibawah umur, oknum bisa mendapatkan celah hukum untuk melegitimasi perbuatan mereka sehingga hal ini menjadi lumrah terjadi pada lingkungan masyarakat. Terdapat berbagai keterangan yang terdapat digambar diatas yaitu :

1. Dicabut artinya pemohon dispensasi nikah yang awalnya memperkarakan anak mereka untuk melakukan perkawinan dibawah umur, akan tetapi dengan berbagai pertimbangan tertentu pemohon melakukan damai atau rukun antara kedua belah pihak.

2. Dikabulkan artinya pemohon dispensasi nikah telah memenuhi semua syarat dan disetujui oleh hakim berdasarkan pertimbangan tertentu.

Sangaji Jurnal Pemikiran Syariah dan Hukum 
3. Gugur artinya pemohon dispensasi nikah tidak menghadiri maksimal 2 kali persidangan atau bahkan tidak menghadiri sama sekali persidangan, maka permohonan dianggap gugur.

4. Tidak dapat diterima artinya pemohon dispensasi nikah dalam mengajukan perkara tidak memiliki cukup bukti untuk membuktikannya maka perkara tersebut berstatus tidak dapat diterima.

Melihat data di atas maka harus perlu ada pengkajian ulang terkait bunyi pasal 7 ayat 2, bagaimana mungkin di satu sisi pasal 7 ayat 1 memberikan batasan umur akan tetapi justru di pasal lain menerangkan bahwa boleh melanggar pasal 7 ayat 1 dengan catatan melakukan permohonan dispensasi nikah, yang perlu di kaji adalah dampak dari anak bangsa yang melakukan perkawinan dibawah umur seperti yang terdapat dipembahasan berikutnya yaitu pertama putus sekolah, berdasarkan hasil wawancara sebelumnya bahwa putus sekolah akan berdampak pada anak yang telah melakukan perkawinan di usia yang muda, kedua mengalami KDRT, akibat dari belum matangnya mental dan secara psikologi belum mampu untuk membangun rumah tangga, ketiga, perceraian adalah dampak terburuk apalagi yang menjadi korban adalah wanita dan menjadi orang tua tunggal sehingga harus menjadi tulang punggung keluarga.

Menjadi faktor utama terwujudnya permohonan dispensasi nikah adalah akibat dari hamil terlebih dahulu sebelumnya melakukan perkawinan, hal ini mencerminkan bahwa pergaulan yang diluar batas nilai moral dan etika pada generasi bangsa mulai mengalami degradasi, padahal secara eksplisit dalam pancasila, UUD 1945 menjunjung tinggi moral sebagaimana yang berbunyi pada sila ke-2 yaitu kemanusiaan yang adil dan beradab, artinya amanat yang disaampaikan oleh ideology bangsa kita yaitu pancasila begitu ekspilisit memaparkannya, hanya saja dilingkup masyarakat tidak mampu untuk menjewantahkan amanat yang dimaksud sehingga berdampaklah pada pergaulan masyarakat 
yang diluar jalur kodrati dan bertentangan dengan aturan yang berlaku.

Maka dari itu pemerintah kota bima khususnya memberikan sebuah solusi untuk menekan perkawinan di bawah umur seperti dari pihak KUA melakukan sosialisasi dampak dari perkawinan di bawah umur, ada rencana kebijakan dari pemerintah untuk melakukan pendidikan pra nikah, dengan mengeluarkan sertifikat bagi calon pengantin sehingga secara mental, psikologi bisa siap untuk membangun rumah tangga.

\section{Simpulan}

Frekuensi perkawinan di bawah umur di Kota Bima mengalami kenaikan tiap tahunnya, hal ini tentunya miris terjadi apalagi Kota Bima terkenal dengan nilai religi yang kental, dengan adanya surat sakti yaitu dispensasi nikah tentunya bisa dimanfaatkan oleh oknum yang paham akan aturan tersebut. Pengajuan dispensasi nikah yang mengajukan adalah walinya yang meminta ijin bisa calonnya juga atau orang yang menurut hukum catatan perkawinan, hal ini dilakukan karena berbagai macam faktor yang terjadi seperti salah satu dari hasil penelitian menunjukan bahwa anak yang melakukan perkawinan dibawah umur sudah terlebi dahulu melakukan hubungan layaknya suami istri dan sebagainnya. Adapun proses persidangan dilakukan secara tertutup selama proses persidangan hal ini sama saja dengan membuka aib pelaku perkawinan dibawah umur, peningakatan praktek perkwinan dibawah umur terus meningkat setiap tahun walaupun pemerintah sudah berusaha dengan berkolaborasi dinas kesehatan akan tetapi tetap saja hal ini tidak mampu ditekan pelaaku perkawinan dibawah umur, maka keseimbangan control dari keluargalah yang berperan penting untuk menjaga dan merawat generasi bangsa ini dengan memperhatikan lingkungan social melalui pergaulannya serta tanamkan nilai-nilai religi pada anak sebagai bekal kelak.

Sangaji Jurnal Pemikiran Syariah dan Hukum 


\section{Daftar Pustaka}

\section{Buku}

Amiruddin dan Zainal Azakin, 2004. Pengantar Metode Penelitian Hukum. Jakarta : Raja Grafindo Persada.

Anshary, M. 2010. Hukum Perkawinan di Indonesia (Masalah-masalah Krusial). Yogyakarta: Pustaka Pelajar

Arikunto, Suharsimi. 2010.Prosedur Penelitian Suatu Pendekatan

Praktik. Jakarta: PT. Rineka Cipta

Gultom, Maidin. 2013. Perlindungan Hukum terhadap Anak dan Perempuan. Bandung: PT. Refika Aditama

Hanif, Yusuf. 2011. Kontroversi Perkawinan Anak dibawah Umur (Child Marriage). Bandung: CV. Mandar Maju

Khaeron Sirin. 2009. Fikih Perkawinan dibawah Umur. Jakarta: Ghalia Indonesia

Kumalasari, Intan dan Andhyantoro, Iwan. 2012. Kesehatan Reproduksi untuk Mahasiswa Kebidanan dan Keperawatan. Jakarta: Salemba Medika.

M. Ali Harakan. 2012. Sirah Nabawiyah. Jakarta : Pustaka AlKautsar

Mohammad, M. Dlori. (2005) Jeratan nikah dini, wabah pergaulan. Yogjakarta: Binar Press.

Nukman, 2009. Yang dimaksud dengan pernikahan dini. Yogyakarta : Paradigma

Sugiyono. 2011. Metode Penelitian Kualitatif, Kuantitatif dan $R \mathcal{E} D$. Bandung : Alfabeta

Wiliam. J. Goode. 1985. Sosiologi Hukum. Alih bahasa Hanoun Hasyim. Jakarta : Diaksara.

\section{Jurnal}

Anisah, Pertimbangan hakim dalam mengabulkan permohonan dispensasi perkawinan anak dibawah umur menurut undangundang nomor 1 tahun1974" (malang :UIN Malang, 2012) 
Maspupah, Ade. 2014. People's Perseption About Early Marriage (A Case Study In Desa Sungai Kuning Kecamatan Singingi Kabupaten Kuantan Singingi). Jom FISIP Volume 1 No( 2), 1 15.

Yuyun, Implementasi Undang-undang No.1 tahun 1947 studi kasus perkawinan dibawah umur. penelitian, (Lombok:2015)

\section{Perundang-Undangan}

Http://sipp.pa-bima.go.id

Kitab Undang-Undang Dasar 1945. 2017 Jakarta: Majelis Permusyawaratan Rakyat

Undang-undang Nomor 23 Tahun 2002 Tentang Perlindungan Perempuan dan Anak

Undang-undang Nomor 39 Tahun 1999 Tentang Hak Asasi Manusia

Undang-undang Republik Indonesia Nomor 1 tahun 1974 tentang Perkawinan dan Kompilasi Hukum Islam. 2014. Jakarta: Grahamedia Press. 